\title{
A Study on Consumers' Preferences for the Palace Museum's Cultural and Creative Products from the Perspective of Cultural Sustainability
}

\author{
Jui-Che Tu ${ }^{1}$, Li-Xia Liu ${ }^{1,2}$ and Yang Cui ${ }^{3, *}$ (i) \\ 1 Graduate School of Design, National Yunlin University of Science and Technology, Yunlin 64002, Taiwan; \\ tujc@yuntech.edu.tw (J.-C.T.); liulixia780729@yahoo.com (L.-X.L.) \\ 2 College of Arts, Beijing Union University, Beijing 100101, China \\ 3 School of Art and Communication, Beijing Technology and Business University, Beijing 100048, China \\ * Correspondence: cy_arc@126.com
}

Received: 24 April 2019; Accepted: 14 June 2019; Published: 26 June 2019

Abstract: In recent years, the development and design of the cultural and creative products of the Palace Museum in Beijing have become a hot topic in the product design field. Many critics have pointed out that cultural and creative products have failed to faithfully convey the implied meanings of the cultural stories of the Palace Museum. To effectively narrow the cognitive gap between designers and consumers, designers must urgently clarify the relationship between different design attributes and consumer preferences. The questionnaires were used to obtain data from 297 subjects. Through SPSS statistical software, the results were analyzed by descriptive statistics, explore factor analysis (EFA), independent sample $t$-test, and ANOVA to explore consumers' attitudes and preferences on the Palace Museum's cultural and creative products. The results showed that consumers attach great importance to factors such as "cultural connotation" and "unique creativity" when choosing the Palace Museum's cultural and creative products. The consumer in different genders had significant differences in the design factors of the Palace Museum's cultural and creative products. There were significant differences in the factors of "Forbidden City culture", "cultural sustainability" and "traditional culture" to different educational backgrounds. There were significant differences in the factor of "Forbidden City culture" to different ages. There were significant differences in the factors of "cultural traits" and "cultural identity" between the with and without a design background groups. The results of this study will identify the key factors for the design of the Palace's Museum cultural and creative products and provide references for designers.

Keywords: cultural sustainability; the Palace Museum; cultural and creative products; consumer preferences; purchasing intention

\section{Introduction}

\subsection{Research Background and Motivation}

"Aesthetics" have rapidly emerged with the advent of the globalized knowledge economy era and the rise of national life demand levels, meaning that the consumer market has entered an era that emphasizes aesthetics and experience economy. Experience economy is based on life and situation, shaping sensory experience and thinking identity, so as to seize the attention of customers, change consumer behavior, and find new survival value and space for commodities. The demand-oriented trend, which features customer focus and the influence of artistry and culture, has extended to the industrial value chain. Thus, the industry must develop aesthetic innovations that consider consumers' cultural foundations [1]. Under the pressure of economic globalization and social transformation, 
China's cultural and creative industry maintains the sustainability of its traditional culture through design creativity, with the expectation of obtaining consumers' satisfaction and purchase intention through a combination of the cultural heritage charm of the Palace Museum and its cultural and creative products, thus, promoting a balance between the economic output value of the Palace Museum and people's quality of life. As Farsani et al. (2011) put it, "Cultural sustainability is the concept for the recovery and protection of cultural identities. It is linked to previous traditional practices by celebrating local and regional histories and passing down cultural values to future generations" [2]. Culture sustainability is one of the indispensable components of sustainability [3]. The Palace Museum developed commemorative commodities taking the collection, exhibition, and characteristics of museums through creative design, life aesthetics, fashion, and other factors to sale in the shop of the Palace Museum. The cultural and creative products of the Palace Museum should better disseminate the splendid traditional culture of the Chinese nation, excavate and utilize the cultural resources of the Palace Museum, give full play to the cultural dissemination and educational functions of the Museum, and create a better combination of traditional Chinese culture and modern fashion, in order to attract public attention to cultural and creative products, promote the integration of historical relics and modern cultural industries, and meet the growing spiritual and cultural needs of the people, and such satisfaction will allow more visitors to "bring the Palace Museum culture home" [4]. It is hoped that more of the cultural resources of the Palace Museum can approach society through creative products, in order to teach more people about Chinese cultural history, and so consumers can be exposed to traditional culture and feel the charm of history when using Palace Museum products.

Since Mr. Shan Jixiang became the chief curator of the Palace Museum in 2012, he has opened the long-closed doors of the Palace Museum, and allows the top cultural relics and traditional Chinese culture, which have long been stored in the warehouse, to walk out of the palace and into the world in the form of cultural and creative products; in this way, he managed to bring the Palace Museum's cultural heritage to life ( $90 \%$ of the relics are stored in the warehouse and not open to the public). The "court beads headphones" (Figure 1), as well as other cultural and creative products produced by the Palace Museum, have become the organic carriers of museum culture, making great contributions to the course of carrying forward our traditional culture, which also entails the development and study of the Palace Museum's cultural and creative products [5]. During an interview with Guangming Daily, Li Xiaojie, the Vice Minister of the Ministry of Culture, National Cultural Heritage Administration, said, "We should strive to excavate the vitality of cultural relics so that they can better serve society and become alive" [6].

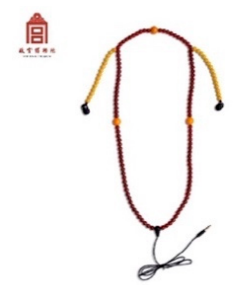

Figure 1. Court beads headphones.

At present, the overall R\&D level of cultural and creative products in Chinese museums is not high, lagging far behind museums in developed countries and regions [7]. As designers have different cognitions of design concepts and expected effects when developing cultural and creative products, design forms present an inconsistent international style without Chinese characteristics, meaning they cannot transmit the important Intellectual Property (IP) information with the cultural imprint of the Palace Museum to consumers. Many critics have pointed out that the cultural and creative products of the Palace Museum do not convey the connotation embedded in its cultural stories. If they only convey the simple grafting product and culture, and cannot give consumers a deep feeling of the historical taste and cultural charm of the Palace Museum, we may fall deep into the strange circle of "seeking quick success and quick profit". Therefore, during the design process of the Palace Museum 
products, the key design considerations place emphasis on combining cultural values with traditional cultural characteristics, digging deeply into cultural connotations, accurately grasping cultural values, refining cultural symbols, and integrating abstract culture into specific products. The exploration of the cultural variables and design attributes from the perspective of cultural sustainability are worthy of consideration and improvement, including industrial circles from the perspectives of consumer cognitive factors, preferences, purchase intentions, etc.

\subsection{Research Purposes and Questions}

The purpose of this study is to explore the design attributes of the Palace Museum's cultural and creative products and to analyze consumers' preference factors for the Palace Museum's cultural and creative products through consumers of different backgrounds at age, gender, education, and design background; for the development of the Palace Museum's cultural and creative products, it is to find the key factors of design; for the cultural and creative product design creativity, to maintain the sustainability of traditional Chinese culture, provide reference suggestions and thinking directions for future designers of cultural and creative products.

According to the International Council of Museums, the mission of a museum is to "acquire, conserve, research, communicate and exhibit the tangible and intangible heritage of humanity and its environment for the purposes of education, study and enjoyment" [8]. Mr. Shan Jixiang said, "Since its inception over 60 years ago, the Palace Museum's Cultural Service Center has produced a series of cultural products, which, however, still cannot be accepted by people. The reason lies in their lack of creativity" [9]. The main problem faced by the cultural and creative products of the Palace Museum is that visitors cannot "take museum culture home". As cultural products cannot attract consumers' purchase intention, it is difficult to realize people's expectation to take the Palace Museum culture home. At present, the Palace Museum's cultural and creative products tend to pursue sales volumes and, thus, fail to embody a deeper culture and tradition.

To address the issues already outlined, the present study was designed to address the following research questions: What characteristics of the Palace Museum's cultural and creative products appear? What are the design attributes that different groups of consumers consider when buying creative products? What cultural factors do consumers consider when buying creative products? Is there a difference in various consumers on the preference of the Palace Museum culture and creative product?

\section{Literature Review}

\subsection{Current Status of The Palace Museum's Cultural and Creative Industry}

The Palace Museum, located in Beijing, China, was found in 1925, originally as the Imperial city of the Ming (1368-1644) and Qing (1644-1911) dynasties. Today, it is one of the most famous museums in China and in the world [10]. On the National Day of China 2015, the east wing-room of Shenwumen was renovated as the "cultural creativity experience hall". The whole experience hall included eight exhibition halls, such as Silk Hall, Clothing Hall, Living Hall, Image Hall, Wood Art Hall, Ceramic Hall, and Forbidden City Book Garden. The exhibition hall covered an area of more than 1000 square meters. It displayed nearly 8000 kinds of unique culture and creative products [11]. Moreover, in 2017, the Palace Museum also designed cultural service areas on both sides of the east and west outside Shenwumen, where visitors do not need to buy tickets and are not restricted by the opening-hour limitations, in order to increase the sales time of cultural and creative products. Cultural and creative products are promoted and sold through multiple channels, such as Wangfujing, Taobao Palace Museum (Taobao is one of the largest online sales platforms in China), Macao Art Museum, and the App Palace Museum. Data show that the Palace Museum's cultural and creative products maintain a rapid growth rate in both quantity and sales year by year. According to incomplete statistics, the Palace Museum increased its cultural and creative products by 195 kinds in 2013, 265 kinds in 2014, and 813 kinds in 2015. In the past three years, it has accumulatively developed 1273 kinds of cultural 
and creative products and has established cooperative relationships with more than 60 enterprises. The sales also increased from RMB 600 million in 2013 to RMB 1 billion in 2016 [12]. As of the end of 2018, the Palace Museum has more than 10,500 cultural and creative products. On 17 February 2019, at the 19th annual meeting of the Abu Li China Entrepreneurs Forum, Mr. Shan Jixiang, the chief curator of the Palace Museum, said that the revenue of the Palace Museum creative products already reached RMB 1.5 billion in 2017 [13]. All these data show that the Forbidden City, which was far removed from the public by its mysterious veil and unattainable art collections in the Palace Museum, is entering our lives in a way welcome by everyone. These elegant, lively, interesting, and refreshing cultural and creative products sent a wave of integration of traditional and modern design into the market [11]. The Palace Museum is committed to the development and progress of cultural and creative industries with two targets: to meet the growing spiritual and cultural needs of the general public, and to "liven up" cultural relic collections in a unique way, thus, giving new life to the cultural relic collections in the Palace Museum, in order for the rich cultural treasures of the Palace Museum to be displayed to the public in a rich, wonderful, vivid, and lively manner [14].

\subsection{Cultural and Creative Products}

\subsubsection{Definition of Cultural and Creative Products}

There is no consensus on the terms of "cultural and creative products"; for example, they are named by the media as "cultural products" [15], "cultural and creative commodities" [16], "museum cultural and creative products" [17,18], "creative goods" [19], and "display derivative products" [20]. Cultural products review and rethink the cultural elements contained in the object itself, and seek to represent such cultural elements through design in a new form that conforms to the modern taste, and to explore the satisfaction of the consumer's spiritual level after using the object [21]. Some researchers hold that museum cultural and creative products generally refer to products "whose designs are derived from the exhibition theme of the museum collections, and which shall bear the extended meanings of museum functions" [22]. Literature also states that "the concept of art derivatives emerged from the semantic environment of western museum commodities, and is widely known to the public, along with the development of the museum retail industry. Therefore, Museum art derivatives are often called creative gifts, museum cultural products, and museum customized goods in current academic and social circles" [23]. For the convenience of discussion, this research collectively adopts the term "Palace Museum's cultural creative products", which refers to the cultural and creative products for sale, namely, museum souvenirs developed by an institution with the attributes and functions of the Palace Museum by integrating the ideas originated from the museum collections, exhibitions, and characteristics with various factors, such as creative design, aesthetics of life, and fashion.

\subsubsection{Design of Cultural and Creative Products}

The design of cultural and creative products is to re-examine and reflect on the cultural factors contained in the objects themselves, and to seek to present their cultural factors with a new modern outlook through design [21]. When designing cultural and creative products, designers must understand the interdependence and interaction relationship between products and cultures: products are the physical manifestations of culture, while cultures are attached to products, and form communication between symbols and meanings [24]. The emphasis of the design of cultural and creative products lies in attracting consumers to understand the connotation conveyed by the design through the designed appearance of the products, which allows consumers to form quality perceptions according to the cultural attribute characteristics of the product's design, and then, generate their overall evaluation. The performance of the cultural attribute characteristics of the products has a significant influence on consumers' willingness to purchase cultural and creative products. Before designing cultural and creative products, designers should have insight into the value of local culture, understand its inherent spirit and meaning, and reinterpret the existing culture and tradition with modern and innovative thinking [25]. Only when designers design 
cultural and creative products that truly reflect Chinese traditional culture, and meet the needs of people's lives, can they create meaningful and stylish products for the Palace Museum.

\subsection{Consumer Preference}

Preference is the collective name of many related factors in economics, including how a person expresses their own value in judgment or behavior, past experience, family life, and social environment. It is widely used in psychology, sociology, and anthropology [26]. Preference has two important concepts: one is that everyone's preference is constantly changing at different times; the other is that everyone is trying to satisfy their own preferences in a way they like, thus, preferences are embodied in all of one's selections of activities [27]. Becker suggested that, before deciding to do anything, people consider both the benefits and risks of their behaviors, where the weights of consideration are determined according to preference. Everyone's preferences for their own needs, such as diet, fashion clothing, and houses, would change with the economy, society, peer pressure, and other factors; while deep preferences are quite stable throughout life. Preference refers to items that consumers consider important and are willing to pay a premium for, and certain preferences would lead to repetitive behaviors. Cultural preference is the counterpart of personal hobbies or tendency, which is relative to culture. Cultural preference is the cognitive tendency of consumers, which is formed under the common cultural environment and the common pursuit of something driven by the common value of the groups. Dr. Zeng Fanwen, Executive Dean of the Institute of Cultural Industry of the Renmin University of China, released the "China Cultural Consumption Index (2017)". The comprehensive index of male cultural consumption surpassed that of female for the first time in 2017. The group aged 18-30 years old had the highest cultural consumption intention and level index, the strongest demand for cultural consumption and the largest actual cultural consumption expenditure, which had become the main force of cultural consumption [28]. College students are the best target group for the development of cultural and creative industries, as they have the ability to quickly accept the culture [29]. Consumers' cultural preferences are reflected in all aspects of consumer behavior, such as commodity preferences. Cultural preferences have the characteristics of universality, diversity, stability, and coerciveness, and consumers are more likely to buy products and services consistent with their own cultural values [30]. Through on-the-spot observation of the Palace Museum store in Beijing, interviews with staff, and data analysis of the Palace Museum Taobao e-commerce platform, it is found that the mainstream consumers who buy Beijing Palace's Museum cultural and creative products are young people under 40 years old [4,7]. According to the above-mentioned theories, preference is an attitude reflecting ones' degree of preference by selection behavior [31].

\subsection{Cultural Sustainability}

Sustainable development is often considered to consist of ecological, economic, and social dimensions, or 'pillars' [32,33]. Nowadays, people are paying more and more attention to the cultural considerations of sustainable development. Hawkes (2001) regarded cultural sustainability as the fourth pillar of sustainable development and emphasized the role of culture in local planning. Culture has often been considered part of social sustainability, socio-cultural sustainability, covering cultural aspects such as equity, participation, and awareness of sustainability [34]. Incorporating culture into development strategies and economic projects can effectively enhance the impact of sustainability [35]. As the concept of sustainability has gradually become an important theoretical support in the field of product design, this concept is taken as the basis for the proposed design strategies of cultural and creative products.

\section{Research Design}

\subsection{Research Subjects}

This research found that the mainstream consumers buying the Palace Museum's cultural and creative products are young people under 40 years old $[4,7,36]$. Therefore, this study selected young 
people aged 18-40 years old as subjects. This study used snowball sampling through social networks to develop a sample between 20 March and 25 March 2019. A total of 322 questionnaires were collected from a young group that bought cultural and creative products. After removing 25 invalid questionnaires, 297 valid questionnaires were collected, which then underwent statistical analysis.

\subsection{Cultural and Creative Product Samples}

This study is based on the sample sources of the Palace Museum official flagship store on Taobao $[37,38]$. The cultural and creative products in this museum are divided into seven categories: The Palace Museum make-up (P1), the Palace Museum dolls (P2), the Palace Museum souvenirs (P3), the Palace Museum handbooks (P4), the Palace Museum stationery (P5), the Palace Museum jewelry (P6), the Palace Museum clothing (P7). Taking cultural and creative products with the highest sales volume in their respective categories in 2018 as samples, graphic cards were encoded and collated (Figure 2), which would serve as the test samples of cultural and creative products in the formal questionnaire, in order to facilitate the subjects' understanding and cognition of cultural and creative products.

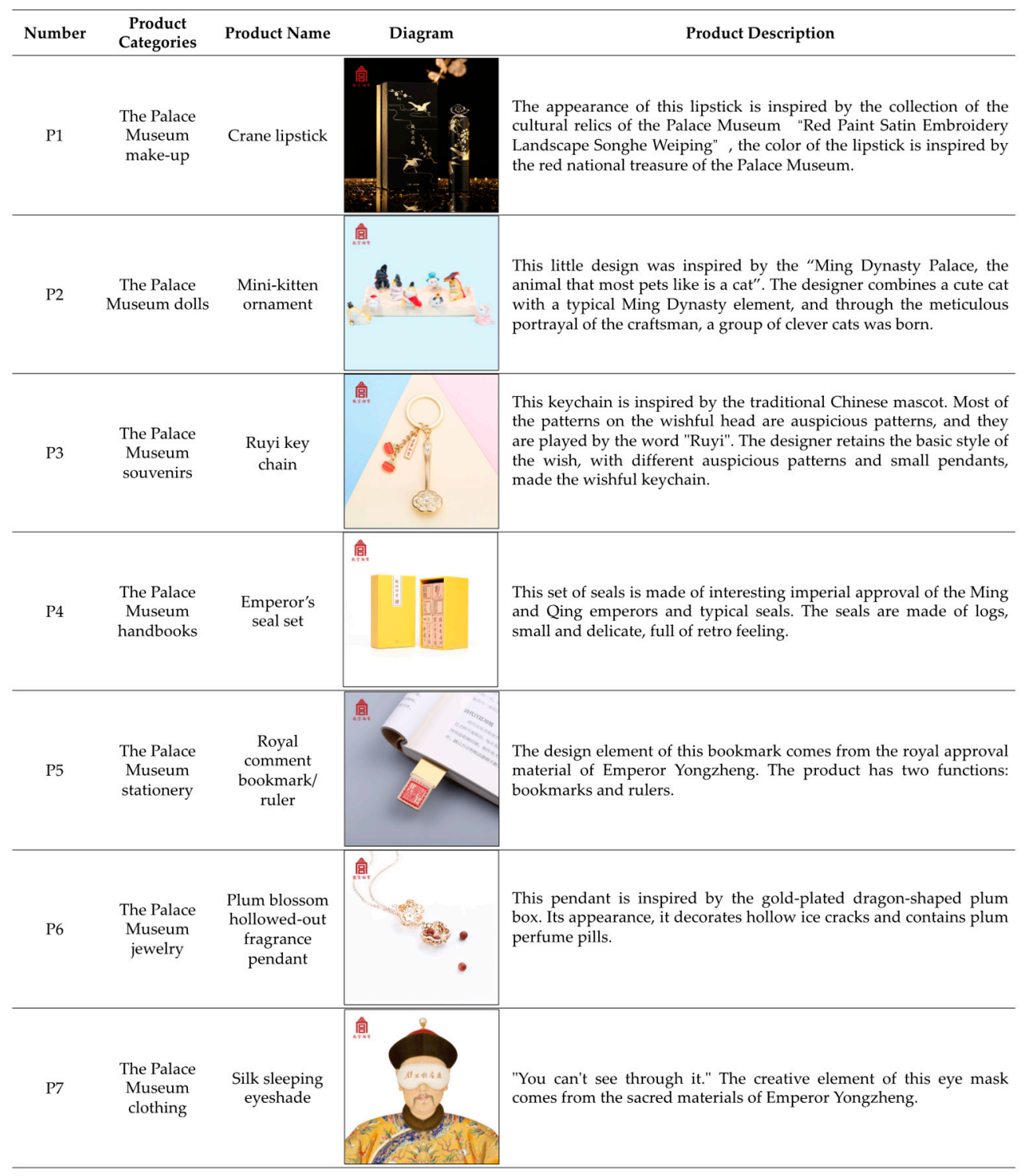

Figure 2. Cultural and creative product samples. 


\subsection{Cultural and Creative Product Attributes Projects}

According to the literature, 32 design attributes of the culture and creative products in related research fields were collected. Six experts in the design field were invited to screen out the unrepresentative items; in total, 15 product attributes were reserved, which were sorted out as Table 1.

Table 1. The contents of the questionnaire were generated according to the relevant literature.

\begin{tabular}{|c|c|}
\hline Source & Questionnaire Contents \\
\hline $\begin{array}{l}\text { (Shang, 2018) [39]; (Xing, 2014) [40]; } \\
\text { (Wang, 2007) [41]; (Kuo, 2003) [42] }\end{array}$ & $\begin{array}{l}\text { Q01.This product has a cultural element of faith and ethics. } \\
\text { Q02.This product can be presented as allusions of old things. } \\
\text { Q03.This product has the special customs of the place, the customs and other images. } \\
\text { Q04.This product makes me feel the characteristics of the royal culture of the Forbidden } \\
\text { City in China. } \\
\text { Q05.This product will make me feel the glory of traditional culture. }\end{array}$ \\
\hline $\begin{array}{l}\text { (Qiang, Ye and Yao, 2018) [43]; } \\
\text { (Wang, 2018) [44]; (Yu and Yang, 2017) } \\
\text { [45]; (Lu and Ma, 2017) [46]; (Xiong, } \\
\text { 2010) [47]; (Shih, 2006) [48] }\end{array}$ & $\begin{array}{l}\text { Q06.The shape of this product can make me feel beautiful. } \\
\text { Q07.This product can make me think of a particular symbol image. } \\
\text { Q08.This product has a unique creativity. } \\
\text { Q09.This product makes me feel a bit interesting. } \\
\text { Q10.This product makes me feel the fashion trend. }\end{array}$ \\
\hline $\begin{array}{l}\text { (Xiao and Wang, 2019) [49]; (Ge, Yu and } \\
\text { Wang, 2018) [50]; (Zhao, 2018) [51]; } \\
\text { (Chen, 2017) [52]; (Zhang, 2016) [53]; } \\
\text { (Jin and Zhang, 2016) [54] }\end{array}$ & $\begin{array}{l}\text { Q11.This product makes me feel the meaning of its cultural value continuation. } \\
\text { Q12.This product makes me feel the historical and cultural memory of the } \\
\text { Chinese nation. } \\
\text { Q13.This product makes me feel that it has a certain cultural meaning. } \\
\text { Q14.This product has the meaning of cultural education and teaching. } \\
\text { Q15.This product reminds me of a specific historical event. }\end{array}$ \\
\hline
\end{tabular}

\subsection{Research Instruments}

Through a literature review and pre-survey, 7 products and 15 design attributes were collected from the samples. For the purpose of this study, the questionnaire was designed in two parts: Part 1: basic personal data, including gender, educational background, age, and design background. Part 2: ranking of consumer preferences, design attributes, cultural and creative product preferences, and scoring of design attributes cognition, and there were 7 cultural and creative product samples in this part. Regarding the cognition attributes, the 15 pre-survey items were used as the test standard for product evaluation, and a Likert 5-point scale was used to score product attribute recognition, as based on the subjective opinions of the subjects. The recognition intensity was divided into 1-5 points, with 5 points indicating the highest attribute intensity, and 1 point indicating the lowest attribute intensity. Consumer preference was ranked according to the subjects' subjective experience and cognition. The products samples were then ranked from No. 1 to No. 7, with No.1 indicating "like the most" and No. 7 indicating "like the least", as shown in Table 2.

Table 2. Structure of the questionnaire.

\begin{tabular}{lc}
\hline \multicolumn{1}{c}{ Questionnaire Classification } & Classification Item \\
\hline Part 1. Basic personal data & Gender/Educational background/Age/Design background \\
\hline Part 2. Consumer preferences & $\begin{array}{c}\text { Design attribute cognition (1 to 5 points) } \\
\text { Cultural and creative product preferences (sorting 1 to 7) }\end{array}$ \\
\hline
\end{tabular}

\subsection{Research Method}

This study was carried out in two stages. The first stage was the pre-investigation: the first stage included the literature research, and then took the official flagship store of the Palace Museum on Taobao as the cultural and creative product samples source, seven test samples were selected, and the design attributes of the representative sample products were screened by collecting the opinions of six experts in the design field. The second stage was a questionnaire survey regarding the cognitive preferences of 297 subjects. SPSS statistics software ver. 23 (IBM, Armonk, NY, USA) was used to 
analyze the survey results. Descriptive statistics, explore factor analysis (EFA), independent sample $t$-test, and ANOVA were conducted to explore consumers' perceptions and preference evaluations of the cultural and creative products of the Palace Museum.

\subsection{Research Architecture and Hypotheses}

This study explored the design preferences of the Palace Museum's cultural and creative products from the perspective of cultural sustainability, and discussions were conducted regarding the variables, such as the gender, educational background, age, and design background. Finally, the survey results were analyzed by SPSS statistical software to further understand the differences in the cognitive preferences and purchase intentions of the Palace Museum's cultural and creative products.

Hypothesis 1. Subjects of different genders have different cognitions of the design attributes of the Palace Museum's cultural and creative product samples.

Hypothesis 2. Subjects with different educational backgrounds have different cognitions of the design attributes of the Palace Museum's cultural and creative product samples.

Hypothesis 3. Different age groups have different cognitions of the design attributes of the Palace Museum's cultural and creative product samples.

Hypothesis 4. Subjects with and without a design background have different cognitions of the design attributes of the Palace Museum's cultural and creative product samples.

\section{Results and Discussion}

\subsection{Descriptive Statistics Analysis}

A detailed analysis was conducted on the subjects' basic personal data items: gender, educational background, age, and design background, as shown in Table 3.

Table 3. Demographic variables.

\begin{tabular}{cccc}
\hline Categories & Items & Frequencies & Percentage \\
\hline \multirow{2}{*}{ Gender } & Male & 130 & $43.8 \%$ \\
\cline { 2 - 4 } & Female & 167 & $56.2 \%$ \\
\hline \multirow{2}{*}{ Educational Background } & University and below & 197 & $66.3 \%$ \\
\cline { 2 - 4 } & Research institute or above & 100 & $33.7 \%$ \\
\cline { 2 - 4 } Age & Under 20 years old & 61 & $20.5 \%$ \\
\cline { 2 - 4 } & 21-30 years old & 125 & $42.1 \%$ \\
\hline \multirow{2}{*}{ Design Background } & 31-40 years old & 111 & $37.4 \%$ \\
\cline { 2 - 4 } & With a design background & 166 & $55.9 \%$ \\
\cline { 2 - 4 } & Without a design background & 131 & $44.1 \%$ \\
\hline
\end{tabular}

\subsection{Analysis of Subjects' Preference in Purchasing Cultural and Creative Products}

\subsubsection{Analysis of Subjects' Preferences}

The 297 subjects' preference degrees for the seven samples of cultural and creative products were ranked, and the results of the narrative statistics are shown in Table 4. 
Table 4. Cultural and creative catalog number and percentage of preferences.

\begin{tabular}{|c|c|c|c|c|c|c|c|}
\hline Product & L1 & L2 & L3 & L4 & L5 & L6 & L7 \\
\hline \multirow{2}{*}{$\mathrm{P} 1$} & 113 & 37 & 31 & 44 & 31 & 26 & 15 \\
\hline & $38 \%$ & $12.5 \%$ & $10.4 \%$ & $14.8 \%$ & $10.4 \%$ & $8.8 \%$ & $5.1 \%$ \\
\hline \multirow{2}{*}{ P2 } & 36 & 43 & 59 & 39 & 50 & 47 & 33 \\
\hline & $12.1 \%$ & $14.5 \%$ & $19.9 \%$ & $13.1 \%$ & $16.8 \%$ & $15.8 \%$ & $11.1 \%$ \\
\hline \multirow{2}{*}{ P3 } & 22 & 57 & 49 & 49 & 40 & 44 & 21 \\
\hline & $7.4 \%$ & $19.2 \%$ & $16.5 \%$ & $16.5 \%$ & $13.5 \%$ & $14.8 \%$ & $7.1 \%$ \\
\hline \multirow{2}{*}{$\mathrm{P} 4$} & 26 & 47 & 48 & 48 & 55 & 51 & 22 \\
\hline & $8.8 \%$ & $15.8 \%$ & $16.2 \%$ & $16.2 \%$ & $18.5 \%$ & $17.2 \%$ & $7.4 \%$ \\
\hline \multirow{2}{*}{ P5 } & 31 & 50 & 56 & 47 & 46 & 57 & 10 \\
\hline & $10.4 \%$ & $16.8 \%$ & $18.9 \%$ & $15.8 \%$ & $15.5 \%$ & $19.2 \%$ & $3.4 \%$ \\
\hline \multirow{2}{*}{ P6 } & 62 & 51 & 40 & 54 & 48 & 37 & 10 \\
\hline & $20.9 \%$ & $17.2 \%$ & $13.5 \%$ & $18.2 \%$ & $16.2 \%$ & $12.5 \%$ & $3.4 \%$ \\
\hline \multirow{2}{*}{ P7 } & 7 & 12 & 14 & 16 & 27 & 35 & 186 \\
\hline & $2.4 \%$ & $4 \%$ & $4.7 \%$ & $5.4 \%$ & $9.1 \%$ & $11.8 \%$ & $62.6 \%$ \\
\hline Total & & & & $\begin{array}{c}297 \\
100 \%\end{array}$ & & & \\
\hline \multirow{3}{*}{$\begin{array}{c}\text { Preference } \\
\text { sort }\end{array}$} & & 息 & & 息 & 息 & & 悬 \\
\hline & & & & ? & & & \\
\hline & P1 & P3 & P2 & P6 & $\mathrm{P} 4$ & P5 & P7 \\
\hline
\end{tabular}

Note: L1 is the first favorite, and so on to L7.

\subsubsection{Statistics of the Average Preference}

The subjects answered 15 questions regarding seven samples of cultural and creative products. A Likert 5-point scale was used, and the subjects were asked to select the degree of attention they attached to the samples, in order to understand the preferences of the subjects for cultural and creative product sample items, as shown in Table 5.

- P1 (crane lipstick): The average value of "cultural meaning" is the highest, indicating that it has the meaning of conveying cultural connotation; the average value of "historical events" is the lowest, indicating that it has a lower function in associating consumers with specific historical events.

- P2 (mini-kitten ornament): The average value of "interestingness" is the highest, indicating that it is interesting; the average value of "cultural image" is the lowest, indicating that it has a lower function in conveying the cultural image of beliefs, ethics, and morality.

- P3 (Ruyi key chain): The average value of "cultural meaning" is the highest, indicating that it has the meaning of conveying cultural connotation; the average value of "historical events" is the lowest, indicating that it has a low function in associating consumers with specific historical events.

- P4 (emperor's seal set): The average value of "Forbidden City royal culture" is the highest, indicating that it has the characteristics of transmitting Chinese Forbidden City royal culture; the average value of "having a sense of the times" is the lowest, indicating that it has a low function in making consumers feel fashion trends.

- P5 (royal comment bookmark/ruler): The average value of "cultural meaning" is the highest, indicating that it has the meaning of conveying cultural connotation; the average values of "having a sense of the times" and "historical events" are the lowest, indicating that it has a lower function in making consumers feel fashion trends and associating consumers with specific historical events. 
- P6 (plum blossom hollowed-out fragrance pendant): The average value of "creating aesthetic feeling" is the highest, indicating that it conveys the feeling of beauty; the average value of "historical events" is the lowest, indicating that it has a low function in associating consumers with specific historical events.

- P7 (silk sleeping eyeshade): The average value of "interestingness" is the highest, indicating that it is interesting; the average value of "cultural image" is the lowest, indicating that it has a low function in transmitting cultural images of belief and ethics.

Table 5. Cultural and creative product samples-the average value of the preference item title.

\begin{tabular}{lcccccccc}
\hline \multicolumn{1}{c}{ Item } & P1 & P2 & P3 & P4 & P5 & P6 & P7 & P1-P7 \\
\hline 1. Cultural imagery & 3.36 & 2.97 & 3.68 & 3.79 & 3.70 & 3.65 & 3.14 & 3.47 \\
\hline 2. Allusions of old things & 3.77 & 3.32 & 3.66 & 3.92 & 3.80 & 3.65 & 3.36 & 3.64 \\
\hline 3. Local customs & 3.89 & 3.49 & 3.86 & 3.86 & 3.76 & 3.85 & 3.31 & 3.72 \\
\hline 4. Forbidden City culture & 3.81 & 3.27 & 3.70 & 4.11 & 3.98 & 3.76 & 3.44 & 3.72 \\
\hline 5. The glory of traditional culture & 3.93 & 3.23 & 3.90 & 4.00 & 3.93 & 3.89 & 3.26 & 3.74 \\
\hline 6. Produce beautiful feeling & 3.98 & 3.80 & 3.89 & 3.71 & 3.90 & 4.12 & 3.15 & 3.79 \\
\hline 7. Symbol imagery & 3.87 & 3.78 & 3.95 & 4.05 & 3.98 & 3.85 & 3.40 & 3.78 \\
\hline 8. Unique creativity & 3.78 & 3.85 & 3.75 & 3.87 & 3.84 & 3.93 & 3.65 & 3.81 \\
\hline 9. Interesting & 3.52 & 4.16 & 3.65 & 3.85 & 3.84 & 3.85 & 3.82 & 3.81 \\
\hline 10. Sense of the times & 3.63 & 3.67 & 3.60 & 3.53 & 3.67 & 3.94 & 3.43 & 3.64 \\
\hline 11. Continuation of cultural values & 3.97 & 3.40 & 3.88 & 3.97 & 4.01 & 3.86 & 3.36 & 3.78 \\
\hline 12. National history and cultural memory & 4.02 & 3.30 & 3.94 & 4.05 & 3.99 & 3.84 & 3.37 & 3.79 \\
\hline 13. Cultural meaning & 4.05 & 3.49 & 3.99 & 4.05 & 4.02 & 3.92 & 3.39 & 3.84 \\
\hline 14. Cultural education and teaching & 3.57 & 3.25 & 3.74 & 3.80 & 3.87 & 3.64 & 3.27 & 3.59 \\
\hline 15. Historical events & 3.22 & 3.06 & 3.37 & 3.72 & 3.67 & 3.52 & 3.27 & 3.41 \\
\hline
\end{tabular}

The average value of "cultural meaning" is the highest in the overall cultural and creative product samples, indicating that it has the meaning of conveying cultural connotation; the average value of "historical events" is the lowest, indicating that it has a lower function in conveying cultural images of beliefs, ethics, and morality.

\subsection{Factor Analysis}

\subsubsection{Reliability Verification and Subjects' Preference Factor Analysis}

Before factor analysis, Kaiser-Meyer-Olkin (KMO) and Bartlett were used to verify the validity of the questionnaire. The KMO value of the questionnaire is 0.939 , and the significance of Bartlett spherical testing is 0.000 . Therefore, the questionnaire meets the requirements of factor analysis, as shown in Table 6.

Table 6. Kaiser-Meyer-Olkin (KMO) and Bartlett's Test.

\begin{tabular}{ccc}
\hline \multicolumn{2}{c}{ Item } & Value \\
\hline Kaiser-Meyer-Olkin Measure of Sampling Adequacy & 0.939 \\
\hline \multirow{2}{*}{ Bartlett's Test of Sphericity } & Approx. Chi-Square & $12,251.805$ \\
\cline { 2 - 3 } & $\mathrm{df}$ & 1653 \\
\cline { 2 - 3 } & Sig. & $0.000 *$ \\
\hline
\end{tabular}

Note: * attains significance level; $p$ value $<0.05$ refers to in conformity with significance. 
After verification, the common factors were extracted by principal component analysis of factor analysis. The value of the rotating axis was selected as the total variance. With a total eigenvalue greater than 1 as the screening condition, the total explained variance was $69.951 \%$ and the lowest eigenvalue was 1.053, which meets the screening criterion of an eigenvalue greater than 1 . According to the criterion of factor load significance, as proposed by Hair et al. (1998), the factor loads reached 0.5, which is within the acceptable range. Finally, 14 factors can be obtained by principal component analysis after rotating the axis. According to the reliability analysis of the factors, Cronbach's $\alpha$ values are all greater than 0.7 , which means that the scale in this paper is reliable. This study named the factors as "culture traits", "local characteristics", "Forbidden City culture", "cultural symbols", "shape with aesthetic feeling", "cultural identity", "unique creativity", "sensual interest", "fashion trend", "cultural sustainability", "traditional culture", "cultural connotation", "cultural heritage", and "historical memory", according to the connotations of the variables contained in the factors, as shown in Table 7.

Table 7. Attribute cognition degree principal component analysis rotated component matrix and reliability analysis.

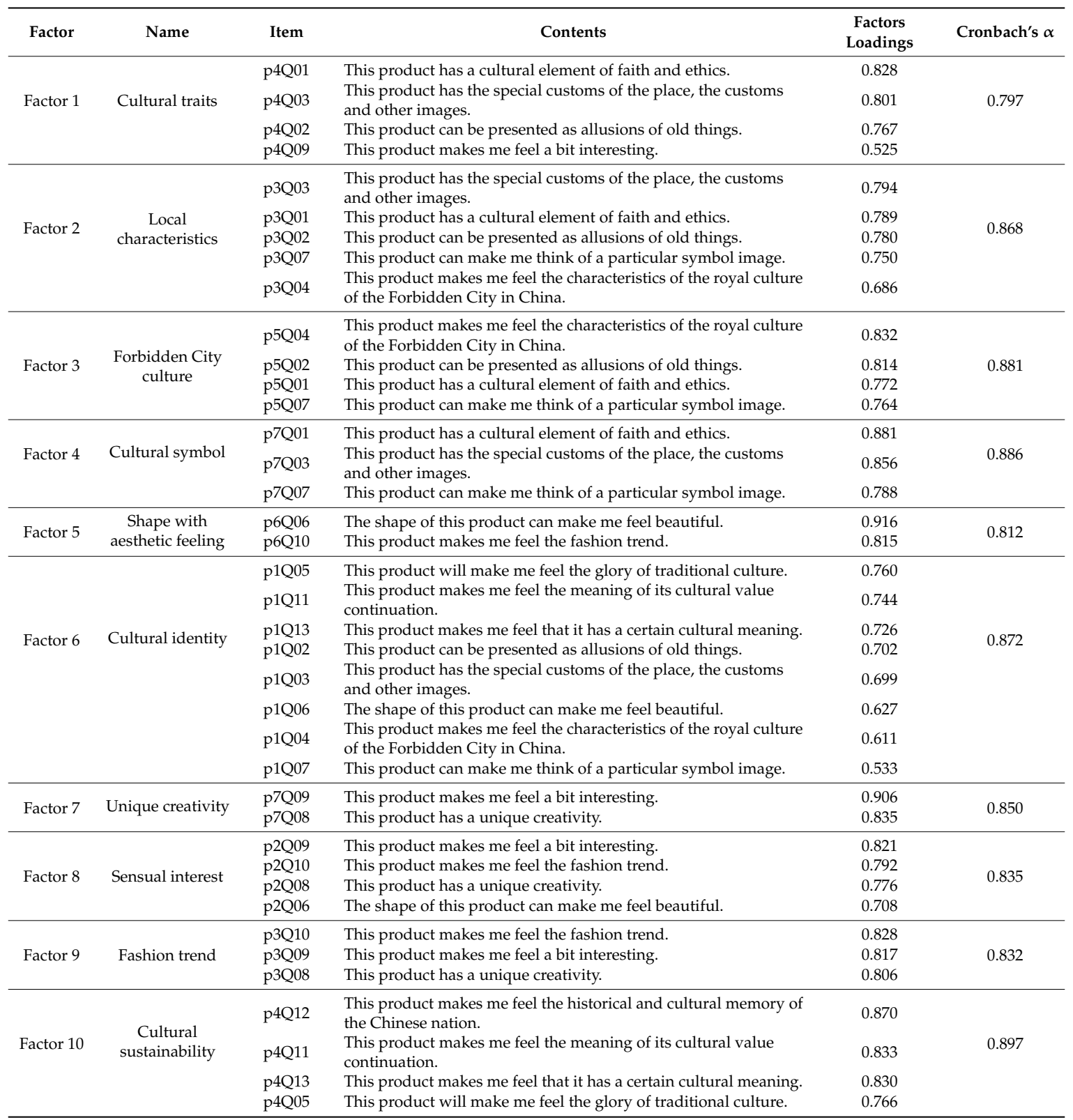


Table 7. Cont.

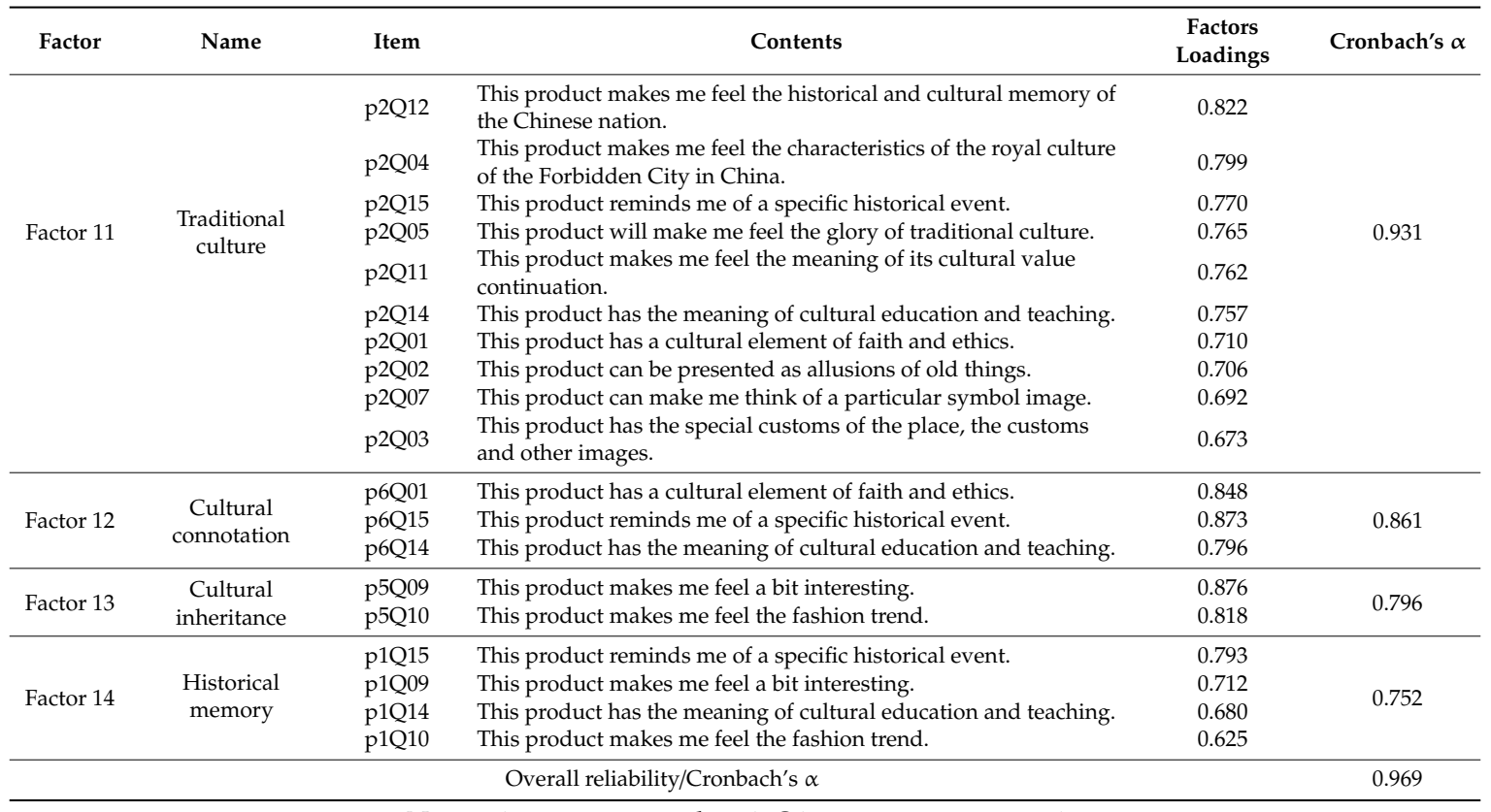

Note: $\mathrm{p} 1$ represents product 1; Q1 represents question 1.

\subsubsection{The Relationship between Cultural and Creative Product Samples and Factors}

According to the results of factor analysis (Table 7), the relationships between seven cultural and creative product samples and their various factors are sorted, as shown in Table 8.

Table 8. Relationship between cultural and creative product samples and factors.

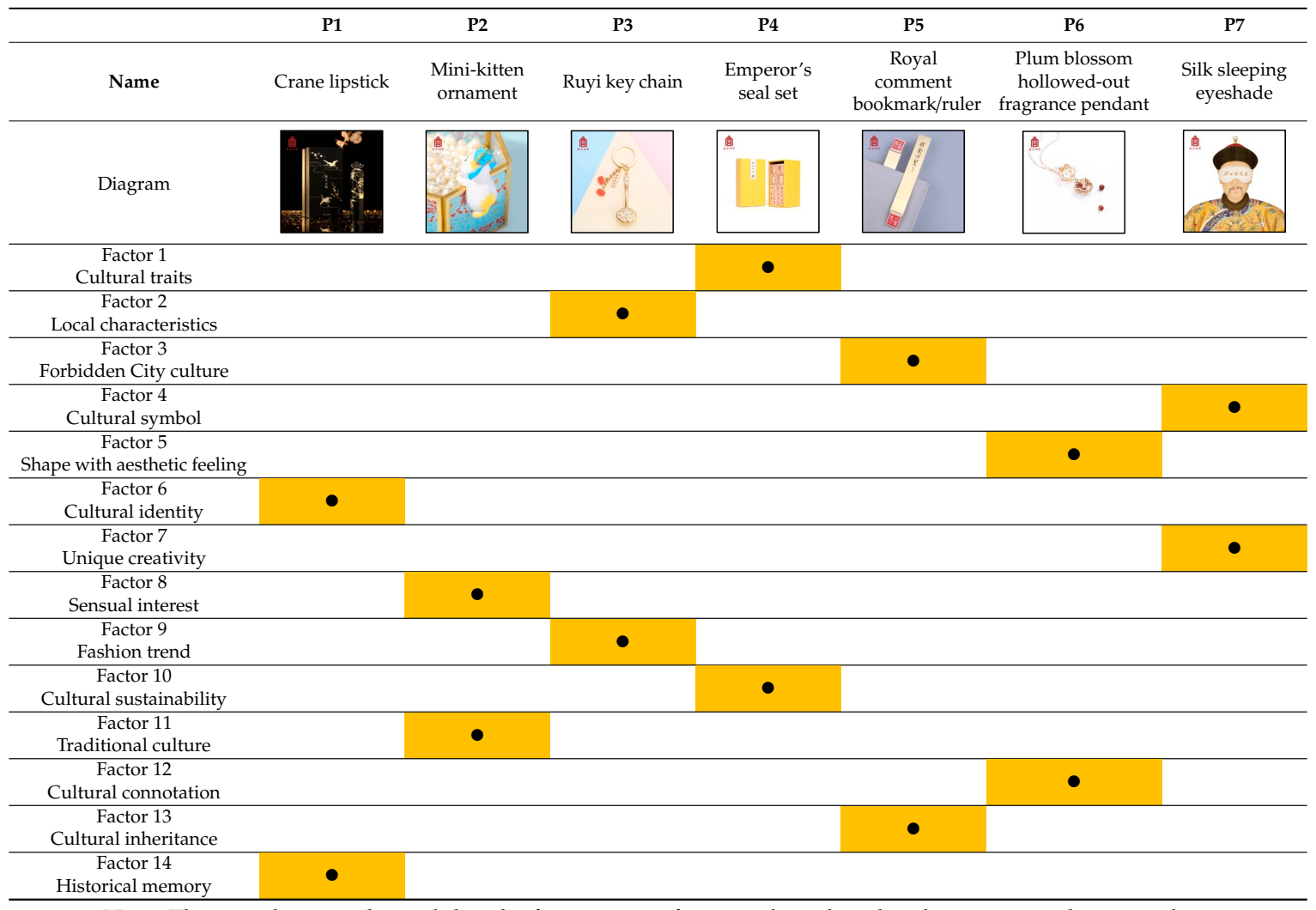

Note: The round points showed that the factor is significant in the cultural and creative product samples. 


\subsection{Analysis of the Subjects' "Cognition of Design Attribute"}

According to the subjects' cognition of design attributes, this research used descriptive statistics as the analysis tool, and collated the mean value of the cultural and creative product sample attributes, in order to understand the data type distribution of the sample, as shown in Table 9.

Table 9. The overall analysis of the subject's cognitive factors.

\begin{tabular}{ccc}
\hline Factor & Mean & SD \\
\hline Cultural connotation & 4.03 & 0.78 \\
\hline Unique creativity & 4.02 & 0.71 \\
\hline Cultural traits & 3.91 & 0.64 \\
\hline Cultural symbol & 3.87 & 0.71 \\
\hline Fashion trend & 3.86 & 0.78 \\
\hline Sensual interest & 3.85 & 0.68 \\
\hline Shape with aesthetic feeling & 3.77 & 0.75 \\
\hline Cultural sustainability & 3.75 & 0.81 \\
\hline Historical memory & 3.74 & 0.98 \\
\hline Cultural identity & 3.67 & 0.80 \\
\hline Traditional culture & 3.60 & 0.85 \\
\hline Local characteristics & 3.49 & 0.71 \\
\hline Cultural inheritance & 3.28 & 0.95 \\
\hline Forbidden City culture & 3.27 & 0.80 \\
\hline
\end{tabular}

According to Table 9, the factor with the highest points is "cultural connotation", followed by "unique creativity"; the factor with the lowest points is "Forbidden City culture". On the whole, all 14 factors of the seven samples are higher than the hypothesis mean value of the 5-point scale, i.e., 3 points, which indicates that the participants tended to acknowledge the 14 factors.

\subsection{Difference Analysis of the Subjects' "Cognition of Design Attribute" Factors}

To further understand the cognitive differences of design attributes among subjects from different backgrounds, based on the 14 factors, this paper explores the differences of product recognition degree according to gender, educational background, age, and design background. Through the analysis of these data, it was confirmed that these data conformed to normal distribution and homogeneity, and are suitable for the following analysis.

\subsubsection{Difference Analysis of Cognitive Factors of Design Attributes According to Gender}

An independent sample $t$-test was used to analyze the differences of cognitive factors between different genders, and the data are sorted, as shown in Table 10.

According to Table 10, there are significant differences in the factors of "cultural trait", "local characteristics", "Forbidden City culture", "cultural symbols", "aesthetic feeling of shape", "unique creativity", "fashion trend", "cultural sustainability", "traditional culture", "cultural connotation", "cultural heritage", and "historical memory". Among them, the average score of females is higher than that of males. While there are obvious differences in "cultural characteristics", "shape with aesthetic feeling", "traditional culture", and "historical memory", these differences are not obvious in the remaining factors. In the ranking of cognitive factors, men attach most importance to the "unique creativity" factor, while women attach most importance to the "cultural connotation" factor. 
Table 10. Differences in gender-to-cognitive factors of design attributes.

\begin{tabular}{|c|c|c|c|c|c|}
\hline \multirow{2}{*}{ Factor } & \multirow{2}{*}{$\begin{array}{c}\text { Male } \\
130\end{array}$} & \multirow{2}{*}{$\begin{array}{c}\text { Female } \\
167\end{array}$} & \multicolumn{2}{|c|}{ Levene's Test for Equality of Variances } & \multirow{2}{*}{ Sig. (2-Tailed) } \\
\hline & & & F & Sig. & \\
\hline Cultural traits & 3.7298 & 4.0494 & 2.299 & 0.131 & $\begin{array}{l}0.000 * \\
0.000\end{array}$ \\
\hline Local characteristics & 3.3615 & 3.5868 & 0.536 & 0.465 & $\begin{array}{l}0.007^{*} \\
0.007\end{array}$ \\
\hline Forbidden City culture & 3.1469 & 3.3587 & 1.338 & 0.248 & $\begin{array}{l}0.024^{*} \\
0.025\end{array}$ \\
\hline Cultural symbol & 3.7173 & 3.9910 & 4.399 & 0.037 & $\begin{array}{l}0.001 \\
0.001 \text { * }\end{array}$ \\
\hline Shape with aesthetic feeling & 3.6015 & 3.9006 & 2.536 & 0.112 & $\begin{array}{l}0.001 \text { * } \\
0.001\end{array}$ \\
\hline Cultural identity & 3.5641 & 3.7445 & 4.058 & 0.045 & $\begin{array}{l}0.053 \\
0.058\end{array}$ \\
\hline Unique creativity & 3.9231 & 4.0943 & 3.360 & 0.068 & $\begin{array}{l}0.038^{*} \\
0.043\end{array}$ \\
\hline Sensual interest & 3.8212 & 3.8802 & 0.342 & 0.559 & $\begin{array}{l}0.459 \\
0.463\end{array}$ \\
\hline Fashion trend & 3.7385 & 3.9626 & 3.803 & 0.052 & $\begin{array}{l}0.014 \text { * } \\
0.017\end{array}$ \\
\hline Cultural sustainability & 3.6038 & 3.8653 & 3.940 & 0.048 & $\begin{array}{l}0.005 \\
0.007^{*}\end{array}$ \\
\hline Traditional culture & 3.4103 & 3.7505 & 0.774 & 0.380 & $\begin{array}{l}0.001 \text { * } \\
0.001\end{array}$ \\
\hline Cultural connotation & 3.8885 & 4.1467 & 0.161 & 0.688 & $\begin{array}{l}0.005^{*} \\
0.005\end{array}$ \\
\hline Cultural inheritance & 3.1590 & 3.3792 & 0.158 & 0.691 & $\begin{array}{l}0.048^{*} \\
0.049\end{array}$ \\
\hline Historical memory & 3.5346 & 3.8952 & 2.207 & 0.138 & $\begin{array}{l}0.002 \text { * } \\
0.002\end{array}$ \\
\hline
\end{tabular}

Note: * attains significance level; $p$ value $<0.05$ refers to in conformity with significance.

4.5.2. Difference Analysis of Cognitive Factors of Design Attributes According to Educational Background

An independent sample $t$-test was used to analyze the differences of cognitive factors among subjects with different educational backgrounds, and these data are sorted, as shown in Table 11.

Table 11. Analysis of differences in cognitive factors of design attributes in the educational context.

\begin{tabular}{|c|c|c|c|c|c|}
\hline \multirow[t]{2}{*}{ Factor } & \multirow{2}{*}{$\begin{array}{c}\begin{array}{c}\text { University } \\
\text { and below }\end{array} \\
197\end{array}$} & \multirow{2}{*}{$\begin{array}{c}\text { Research Institute } \\
\text { or above }\end{array}$} & \multicolumn{2}{|c|}{$\begin{array}{c}\text { Levene's Test for Equality of } \\
\text { Variances }\end{array}$} & \multirow[t]{2}{*}{ Sig. (2-Tailed) } \\
\hline & & & $\mathbf{F}$ & Sig. & \\
\hline Cultural traits & 3.9175 & 3.8938 & 3.092 & 0.080 & $\begin{array}{l}0.763 \\
0.774\end{array}$ \\
\hline Local characteristics & 3.5393 & 3.3875 & 0.362 & 0.548 & $\begin{array}{l}0.083 \\
0.077\end{array}$ \\
\hline Forbidden City culture & 3.3726 & 3.0560 & .228 & 0.633 & $\begin{array}{l}0.001 * \\
0.002\end{array}$ \\
\hline Cultural symbol & 3.8947 & 3.8250 & 1.370 & 0.243 & $\begin{array}{l}0.428 \\
0.443\end{array}$ \\
\hline Shape with aesthetic feeling & 3.7655 & 3.7780 & 1.470 & 0.226 & $\begin{array}{l}0.892 \\
0.896\end{array}$ \\
\hline Cultural identity & 3.6836 & 3.6300 & 1.096 & 0.296 & $\begin{array}{l}0.586 \\
0.594\end{array}$ \\
\hline
\end{tabular}


Table 11. Cont.

\begin{tabular}{|c|c|c|c|c|c|}
\hline \multirow[t]{2}{*}{ Factor } & \multirow{2}{*}{$\begin{array}{c}\begin{array}{c}\text { University } \\
\text { and below }\end{array} \\
197\end{array}$} & \multirow{2}{*}{$\begin{array}{c}\begin{array}{c}\text { Research Institute } \\
\text { or above }\end{array} \\
100\end{array}$} & \multicolumn{2}{|c|}{$\begin{array}{c}\text { Levene's Test for Equality of } \\
\text { Variances }\end{array}$} & \multirow[t]{2}{*}{ Sig. (2-Tailed) } \\
\hline & & & $\mathbf{F}$ & Sig. & \\
\hline Unique creativity & 3.9898 & 4.0775 & 1.364 & 0.244 & $\begin{array}{l}0.312 \\
0.330\end{array}$ \\
\hline Sensual interest & 3.8909 & 3.7825 & 0.313 & 0.576 & $\begin{array}{l}0.195 \\
0.200\end{array}$ \\
\hline Fashion trend & 3.9036 & 3.7875 & 2.008 & 0.157 & $\begin{array}{l}0.227 \\
0.252\end{array}$ \\
\hline Cultural sustainability & 3.8198 & 3.6150 & 0.677 & 0.411 & $\begin{array}{l}0.039 * \\
0.045\end{array}$ \\
\hline Traditional culture & 3.7005 & 3.4067 & 0.264 & 0.608 & $\begin{array}{l}0.005^{*} \\
0.005\end{array}$ \\
\hline Cultural connotation & 3.9924 & 4.1150 & 0.020 & 0.886 & $\begin{array}{l}0.202 \\
0.194\end{array}$ \\
\hline Cultural inheritance & 3.3350 & 3.1800 & 0.017 & 0.897 & $\begin{array}{l}0.186 \\
0.187\end{array}$ \\
\hline Historical memory & 3.6980 & 3.8150 & 2.176 & 0.141 & $\begin{array}{l}0.332 \\
0.349\end{array}$ \\
\hline
\end{tabular}

Note: * attains significance level; $p$ value $<0.05$ refers to in conformity with significance.

As shown in Table 11, there are significant differences in the factors of "Forbidden City culture", "cultural sustainability", and "traditional culture", but not in the other factors. Among them, the average scores of the groups below the university level are higher than those above the graduate school level. In the ranking of cognitive factors, all subjects attach great importance to the "cultural connotation" factor.

\subsubsection{Difference Analysis of the Cognitive Factors of Design Attributes According to Age}

ANOVA F-testing was used to analyze the differences in cognitive factors among the subjects of different ages, and these data are sorted, as shown in Table 12.

Table 12. Analysis of the differences in age-to-design attributes.

\begin{tabular}{|c|c|c|c|c|c|c|c|}
\hline & & SS & DF & MS & $\mathbf{F}$ & Sig. & Scheffe \\
\hline \multirow{3}{*}{ Cultural traits } & Between Groups & 0.306 & 2 & 0.153 & 0.372 & 0.690 & \\
\hline & Within Groups & 120.996 & 294 & 0.412 & & & \\
\hline & Total & 121.303 & 296 & & & & \\
\hline \multirow{3}{*}{$\begin{array}{c}\text { Local } \\
\text { characteristics }\end{array}$} & Between Groups & 1.297 & 2 & 0.648 & 1.278 & 0.280 & \\
\hline & Within Groups & 149.162 & 294 & 0.507 & & & \\
\hline & Total & 150.459 & 296 & & & & \\
\hline \multirow{3}{*}{$\begin{array}{l}\text { Forbidden City } \\
\text { culture }\end{array}$} & Between Groups & 8.057 & 2 & 4.029 & 6.512 & $0.002 *$ & \multirow{3}{*}{$\begin{array}{l}3<1 \\
3<2\end{array}$} \\
\hline & Within Groups & 181.889 & 294 & 0.619 & & & \\
\hline & Total & 189.947 & 296 & & & & \\
\hline \multirow{3}{*}{ Cultural symbol } & Between Groups & 1.835 & 2 & 0.918 & 1.808 & 0.166 & \\
\hline & Within Groups & 149.176 & 294 & 0.507 & & & \\
\hline & Total & 151.011 & 296 & & & & \\
\hline \multirow{3}{*}{$\begin{array}{l}\text { Shape with } \\
\text { aesthetic feeling }\end{array}$} & Between Groups & 0.612 & 2 & 0.306 & 0.547 & 0.579 & \\
\hline & Within Groups & 164.356 & 294 & 0.559 & & & \\
\hline & Total & 164.967 & 296 & & & & \\
\hline
\end{tabular}


Table 12. Cont.

\begin{tabular}{|c|c|c|c|c|c|c|c|}
\hline & & SS & DF & MS & $\mathbf{F}$ & Sig. & Scheffe \\
\hline \multirow{3}{*}{ Cultural identity } & Between Groups & 1.052 & 2 & 0.526 & 0.824 & 0.440 & \\
\hline & Within Groups & 187.725 & 294 & 0.639 & & & \\
\hline & Total & 188.777 & 296 & & & & \\
\hline \multirow{3}{*}{$\begin{array}{l}\text { Unique } \\
\text { creativity }\end{array}$} & Between Groups & 2.073 & 2 & 1.036 & 2.098 & 0.125 & \\
\hline & Within Groups & 145.254 & 294 & 0.494 & & & \\
\hline & Total & 147.326 & 296 & & & & \\
\hline \multirow{3}{*}{ Sensual interest } & Between Groups & 0.430 & 2 & 0.215 & 0.462 & 0.631 & \\
\hline & Within Groups & 136.710 & 294 & 0.465 & & & \\
\hline & Total & 137.139 & 296 & & & & \\
\hline \multirow{3}{*}{ Fashion trend } & Between Groups & 0.268 & 2 & 0.134 & 0.219 & 0.804 & \\
\hline & Within Groups & 180.340 & 294 & 0.613 & & & \\
\hline & Total & 180.608 & 296 & & & & \\
\hline \multirow{3}{*}{$\begin{array}{c}\text { Cultural } \\
\text { sustainability }\end{array}$} & Between Groups & 0.671 & 2 & 0.336 & 0.513 & 0.599 & \\
\hline & Within Groups & 192.391 & 294 & 0.654 & & & \\
\hline & Total & 193.062 & 296 & & & & \\
\hline \multirow{3}{*}{$\begin{array}{l}\text { Traditional } \\
\text { culture }\end{array}$} & Between Groups & 3.144 & 2 & 1.572 & 2.196 & 0.113 & \\
\hline & Within Groups & 210.486 & 294 & 0.716 & & & \\
\hline & Total & 213.630 & 296 & & & & \\
\hline \multirow{3}{*}{$\begin{array}{l}\text { Cultural } \\
\text { connotation }\end{array}$} & Between Groups & 1.228 & 2 & 0.614 & 1.004 & 0.368 & \\
\hline & Within Groups & 179.935 & 294 & 0.612 & & & \\
\hline & Total & 181.163 & 296 & & & & \\
\hline \multirow{3}{*}{$\begin{array}{l}\text { Cultural } \\
\text { inheritance }\end{array}$} & Between Groups & 2.039 & 2 & 1.019 & 1.121 & 0.327 & \\
\hline & Within Groups & 267.315 & 294 & 0.909 & & & \\
\hline & Total & 269.354 & 296 & & & & \\
\hline \multirow{3}{*}{$\begin{array}{l}\text { Historical } \\
\text { memory }\end{array}$} & Between Groups & 0.889 & 2 & 0.445 & 0.461 & 0.631 & \\
\hline & Within Groups & 283.626 & 294 & 0.965 & & & \\
\hline & Total & 284.515 & 296 & & & & \\
\hline
\end{tabular}

Note: * attains significance level; $p$ value $<0.05$ refers to in conformity with significance; Note: (1) Under 20 years old, (2) 21-30 years old, (3) 31-40 years old.

As shown in Table 12, there are significant differences in the factor of "Forbidden City culture", but not in the other factors. Further post hoc comparative analysis shows that the groups under 20 and 21-30 years old obtain higher scores than those aged 31-40 years old in the factor of "Forbidden City culture".

4.5.4. Difference Analysis of Cognitive Factors of Design Attributes According to Design Background

An independent sample $t$-test was used to analyze whether there are any differences in cognitive factors among subjects with and without a design background, and these data are sorted, as shown in Table 13.

Table 13 shows that there are significant differences in the "cultural trait" and "cultural identity" factors, but not in the other factors. In the "cultural trait" factor, there are design background groups higher than no design background groups. In the "cultural identity" factor, the group without a design background obtains higher scores than the group with a design background. The group with a design background pays more attention to the "cultural connotation" factor, while the group without a design background pays more attention to the "unique creativity" factor. 
Table 13. Analysis of differences in attribute cognition factors with or without design background.

\begin{tabular}{|c|c|c|c|c|c|}
\hline \multirow[t]{2}{*}{ Factor } & \multirow{2}{*}{$\begin{array}{c}\begin{array}{c}\text { With a Design } \\
\text { Background }\end{array} \\
166 \\
\end{array}$} & \multirow{2}{*}{$\begin{array}{c}\begin{array}{c}\text { Without a Design } \\
\text { Background }\end{array} \\
131 \\
\end{array}$} & \multicolumn{2}{|c|}{$\begin{array}{c}\text { Levene's Test for Equality of } \\
\text { Variances }\end{array}$} & \multirow[t]{2}{*}{ Sig. (2-Tailed) } \\
\hline & & & $\mathbf{F}$ & Sig. & \\
\hline Cultural traits & 3.9789 & 3.8216 & 0.001 & 0.977 & $\begin{array}{l}0.035^{*} \\
0.036\end{array}$ \\
\hline Local characteristics & 3.4729 & 3.5076 & 1.170 & 0.280 & $\begin{array}{l}0.677 \\
0.676\end{array}$ \\
\hline Forbidden City culture & 3.2404 & 3.2985 & 2.826 & 0.094 & $\begin{array}{l}0.536 \\
0.531\end{array}$ \\
\hline Cultural symbol & 3.9367 & 3.7882 & 3.632 & 0.058 & $\begin{array}{l}0.075 \\
0.070\end{array}$ \\
\hline Shape with aesthetic feeling & 3.8361 & 3.6855 & 0.007 & 0.934 & $\begin{array}{l}0.084 \\
0.085\end{array}$ \\
\hline Cultural identity & 3.5723 & 3.7837 & 8.690 & 0.003 & $\begin{array}{l}0.023 \\
0.020 *\end{array}$ \\
\hline Unique creativity & 4.0678 & 3.9580 & 0.152 & 0.697 & $\begin{array}{l}0.184 \\
0.187\end{array}$ \\
\hline Sensual interest & 3.8720 & 3.8321 & 1.007 & 0.316 & $\begin{array}{l}0.617 \\
0.613\end{array}$ \\
\hline Fashion trend & 3.9157 & 3.7996 & 0.001 & 0.972 & $\begin{array}{l}0.204 \\
0.210\end{array}$ \\
\hline Cultural sustainability & 3.7771 & 3.7176 & 0.037 & 0.848 & $\begin{array}{l}0.529 \\
0.528\end{array}$ \\
\hline Traditional culture & 3.6084 & 3.5929 & 0.000 & 0.999 & $\begin{array}{l}0.876 \\
0.876\end{array}$ \\
\hline Cultural connotation & 4.0994 & 3.9504 & 1.050 & 0.306 & $\begin{array}{l}0.103 \\
0.102\end{array}$ \\
\hline Cultural inheritance & 3.3092 & 3.2494 & 0.726 & 0.395 & $\begin{array}{l}0.592 \\
0.595\end{array}$ \\
\hline Historical memory & 3.7861 & 3.6756 & 1.379 & 0.241 & $\begin{array}{l}0.335 \\
0.330\end{array}$ \\
\hline
\end{tabular}

Note: * attains significance level; $p$ value $<0.05$ refers to in conformity with significance.

\subsection{Discussions on Results and Impacts}

(1) The subjects obtained scores higher than the hypothetical mean value of the Likert 5-point scale, i.e., 3 points were given to all 14 factors of the seven samples of cultural and creative products in this study, indicating that the subjects tended to acknowledge the 14 factors as a whole.

(2) P1 "crane lipstick" has the factors of "cultural identity" and "historical memory"; the appearance pattern of the crane lipstick is inspired by the Palace Museum collection of cultural relics "silk embroidered landscape pine crane fence with red lacquer edge", and the color of the red lipstick is inspired by the red national treasures found in the Palace Museum. This product makes people feel that the scenery or objects are associated with specific historical events. It has the effect of being recognized by the group culture, which makes the subjects feel the charm of history when using the Palace Museum's cultural and creative products. P2 "mini-kitten ornament" has the factors of "sensibility interest" and "traditional culture", as this small ornament is designed with the inspiration that the "Cat is the most popular and favorite pet in the palace of the Ming Dynasty. The designer combines a cute kitten with typical Ming Dynasty elements". This product can make people feel quite interested and has the function of historical and cultural memories. P3 "Ruyi key chain" has the factors of "local characteristics" and "fashion trend". This key chain originates from the traditional Chinese mascot "Ruyi", which was first introduced in the Qin and Han Dynasties as a backscratcher. After a long historical evolution, it gradually surpassed its practical function and became a token of auspice. This product makes people feel images of unique cultures and customs, and also functions as a fashion trend. P4 "Emperor's seal set" has the factors of "cultural trait" and "cultural sustainability". 
The designer of this set of seals selected the interesting imperial comments of the Ming and Qing emperors and the typical imperial seals. The seals are made of logs, which are small and delicate and full of vintage feelings. This product makes people feel cultural elements, such as cultural relics and concepts, and has the function of cultural value sustainability. P5 "royal comment bookmark/ruler" has the factors of "Forbidden City culture" and "cultural inheritance". The text planning elements of this bookmark originated from the memorials of Emperor Yongzheng's royal comments. This product has two functions, meaning it can be used as both a bookmark and a ruler. This product makes people feel the imperial culture of the Forbidden City, and also has the functions of cultural education and imparting knowledge. P6 "plum blossom hollow-out fragrance pendant" has the factors of "shape with aesthetic feeling" and "cultural connotation". This fragrance pendant originates from the "plum blossom-shaped box with painted gold-inlaid clouds and dragon pattern". The designer took the shape of the plum blossom box, decorated it with hollow ice crack patterns, and plum blossom balls are stored inside it. This product gives people the feeling and perception of beauty, and also has certain functions of cultural meaning. P7 "Silk sleeping eyeshade" has the factors of "cultural symbols" and "unique creativity". The creative elements of this eyeshade come from the memorials of Emperor Yongzheng's royal comments. "I can't see it through" comes from Emperor Yongzhen's comment regarding "Guangdong Governor Hao Yulin's memorial of gratitude for Your Majesty's offerings of a mink hat and other things". This product reminds people of specific symbolic images, while showing unique creativity and ingenuity.

(3) The test results show that the factor with the highest score is "cultural connotation", followed by "unique creativity", which indicates that the respondents attach great importance to this factor when choosing cultural and creative products, and shows that the greatest highlight of the design lies in the clever integration of classical and modern cultural elements. Taking P1 "crane lipstick" as the example, a crane implies prolonging life in traditional Chinese culture, while cloud patterns imply harmony, luck, success, and the realization of wishes. For P3 "Ruyi key chain", Ruyi is a token of good luck; for P6 "plum blossom hollow-out fragrance pendant", the plum blossom is a symbol of evergreen and vigorous vitality. It further proves that, while developing cultural and creative products, emphasis on the integration of cultural value and the connotations of products embodying the traditional culture that characterizes the Palace Museum have become the key consideration factors during the design process. On the one hand, it is necessary to enhance the cultural connotation and creative content of the products to meet people's increasing demand for cultural consumption; on the other hand, it is important to combine the aesthetic value and functional value of cultural products, such as the Palace Museum's cultural and creative products, which combine creativity with life and are living goods with collection value [55].

(4) Difference analysis of the cognitive factors of design attributes in cultural and creative products to samples from the subjects.

Hypothesis 1. Subjects of different genders have different cognitions regarding the design attributes of the cultural and creative product samples of the Palace Museum.

There are significant differences in the factors of "cultural trait", "local characteristics", "Forbidden City culture", "cultural symbols", "design with aesthetic feeling", "unique creativity", "fashion trend", "cultural sustainability", "traditional culture", "cultural connotation", "cultural inheritance", and "historical memory". Female subjects obtained higher average scores for design attribute cognition, as compared with male subjects. In the ranking of the cognitive factors, males attach most importance to the "unique creativity" factor, while females attach the most importance to the "cultural connotation" factor, indicating that men pay more attention to the appearance of the cultural and creative products, while women pay more attention to the connotations of cultural and creative products.

Hypothesis 2. Subjects with different educational backgrounds have different cognitions of the design attributes of the cultural and creative product samples of the Palace Museum. 
There are significant differences in the factors of "Forbidden City culture", "cultural sustainability", and "traditional culture". Compared with the group of graduate school level or above, the groups of college and lower education levels pay more attention to other information, such as the Forbidden City royal culture and the sustainability of Chinese traditional culture anticipated to be conveyed by the cultural and creative products. Farsani et al. (2011) put it, "Cultural sustainability is the concept for the recovery and protection of cultural identities. It is linked to previous traditional practices by celebrating local and regional histories and passing down cultural values to future generations" [2]. Culture sustainability is one of the indispensable components of sustainability [3]. From the perspective of the consumer level, college students are the best target group for the development of cultural and creative industries, as they have the ability to quickly accept the culture, and are willing and able to quickly accept new, peculiar, and special things. Disseminating traditional culture in the form of cultural and creative products is the most effective way to attract the attention of this group and arouse their good impression [29]. In the ranking of cognitive factors, all subjects attach great importance to the "cultural connotation" factor. This fully manifests that, while developing and designing cultural and creative products in the future, designers should extract representative elements from the Palace Museum royal culture, and combine the characteristics and connotations of traditional Chinese culture with cultural symbols and modern elements to create cultural and creative products that are practical, aesthetic, and have cultural implications.

Hypothesis 3. Different age groups have different cognitions of the design attributes of the cultural and creative product samples of the Palace Museum.

There are significant differences in the factor of "Forbidden City culture", which shows that the group under 30 years old has a higher cognitive level than the group above 31-40 years old, which indicates that the group under 30 years old pays more attention to the meaning of imperial culture in the Forbidden City in the design of cultural and creative products. While designing the cultural and creative products of the Palace Museum, the designers can add more elements that represent the royalty and aristocracy identity, as accepted by general consumers, such as "I, as the Emperor", "I, as the Empress (or other harem titles)". Such additional design elements can provide a social contact symbol to propagate among college students (under 30 years old) and provide differentiated features for cultural and creative products [28].

Hypothesis 4. Subjects with and without a design background have different cognitions of the design attributes of the cultural and creative product samples of the Palace Museum.

There are significant differences in the "cultural trait" and "cultural identity" factors. In terms of "Forbidden City culture", there are design background groups higher than those without design background groups, this indicates that the design background group pays more attention to the cultural elements of the beliefs and ethics presented by cultural and creative products. In the design of cultural and creative products based on brand communication, cultural traits are extremely important because it is the key to displaying brand image [56]. Therefore, design background groups, in the purchase of cultural and creative products, attach great importance to this factor. On the "cultural identity" factor, the group without a design background obtained higher scores than the group with a design background, which indicates that the group without a design background pays more attention to the traditional cultural connotations presented in the design of cultural and creative products and recognized by the public. When choosing cultural and creative products, consumers must deeply understand and acknowledge the culture behind the cultural products, in order to be stimulated to buy such products; otherwise, they may not purchase such products due to psychological resistance resulting from the pressure of cultural acceptance. The group with a design background pays more attention to the factor of "cultural connotation", which indicates that, when choosing cultural and 
creative products, this group demands certain cultural connotations, in addition to product function and the aesthetic feelings of the shape.

(5) Analysis of subjects' preferences for samples of cultural and creative products.

The order of preferences is as follows: L1 "crane lipstick"; L2 Ruyi key chain; L3 mini-kitten ornament; L4 plum blossom hollow-out fragrance pendant; L5 Emperor's seal set; L6 royal comment bookmark/rule; L7 silk sleeping eyeshade. This shows that the respondents like the "crane lipstick" the most, and are most willing to buy it, as its "cultural recognition" and "historical memory" factors are widely acknowledged by consumers. This is consistent with the news report of the China Economic Information Network on December 12, 2018: 3000 "crane lipsticks" were sold within one hour, ranking this product at the top of the sales list [57]. The Palace Museum took off with its "creativity", and its renown cultural and creative IP joint makeup products became emerging internet celebrities [55]. One of the best-selling and most popular products is the "mini Palace Museum kitten ornament", which achieved 16,000 monthly sales, and was described by numerous buyers as being "very lovely" and "so cute" [36].

(6) Discussion in design and culture sustainability.

The present findings of this study contribute to the field's understanding of consumers' attitudes on traditional cultural attributes in products. We found that the field's understanding is relatively high in regard to consumers' recognition of traditional culture. People expect traditional products to be more suitable for modern people's aesthetic and value expectations [58-60]. The Palace Museum culture and creative products played an intermediary role in promoting sustainable economic, social and ecological development [61-63]. The goals of sustainable development essentially depend on human cognition, action, and behavior, which, in turn, are embedded in cultural sustainability $[58,61]$. While achieving cultural sustainability, it embodies the participation and fairness of consumers in culture and design.

\section{Conclusions and Suggestions}

\subsection{Conclusions}

As an important value-added composition of the museum culture system of the Palace Museum, cultural and creative products play an important role in disseminating cultures and enhancing cultural self-confidence and cultural heritage. The museum could take advantage of its collections of cultural essence to apply cultural creativity to the extension and expansion of its museum functions and provide people with better services through "IP cultural and creative products". In this way, it will exert an imperceptible influence on people's perceptions of improved cultural quality and contribute to the inheritance and development of the essence of Chinese history and culture. Taking the Palace Museum official flagship store on Taobao as a product sample source, this study explored consumers' cognition and preference for cultural and creative products by means of a questionnaire survey, in order to maintain the sustainable development of traditional culture and promote the development of Chinese cultural and creative industries. This study also identified the key design factors and brought forward new reference suggestions and consideration orientations for the design and development of the cultural and creative products of the Palace Museum. Meanwhile, it could serve as an important theoretical basis for the "sustainable design" of products and has great significance for the sustainable development of the product design industry. It could also provide references for follow-up product designs, marketing plans, and enterprise management.

\subsection{Suggestions}

As cultural and creative industries involve a wide range of aspects, there are many factors affecting consumers' cognition of cultural and creative products. Due to the limitations of human resources, time, and space, there is still some room for improvement in this study. The following suggestions are put forward for the reference of follow-up research. 
(1) The product sample of this study is limited, and it is impossible to deeply detect the main attribute factors that cause this difference. Therefore, more in-depth exploration can be conducted on test groups, in order to provide a reference for group positioning during future product design.

(2) Future research can conduct analysis and discussions on specific product categories to make more accurate evaluations of the attributes of cultural and creative products.

(3) The research scope of this study is limited due to various factors, such as manpower and time restrictions; for example: (1) Most of the subjects are teachers and students from universities and institutes, and most of them are from design-related fields with more than one year's relevant experience, which may lead to limitations on the universality of the results. (2) The subjects are mainly young people aged 18-40 years old. It is hoped that future studies can expand the age range of the subjects and test their preferences after dividing them into groups, as based on their lifestyles. (3) As this study adopted an online questionnaire, the genders cannot be effectively controlled; thus, there are more female respondents than male respondents. (4). Product samples are presented in pictures and words; however, as static pictures cannot provide the complete sensory experience of the actual cultural and creative product samples, there may be some errors in the test results.

Author Contributions: All the authors contributed to the paper. L.-X.L. collected and organized the data, L.-X.L.; Y.C. wrote the manuscript with the supervision from J.-C.T. and Y.C. acted as a corresponding author.

Funding: This research was funded by "The Young Teachers Science Research Ability Enhancing Project 2018 of Beijing Technology and Business University", grant number: PXM2018_014213_000033.

Conflicts of Interest: The authors declare no conflict of interest.

\section{References}

1. Shih, B.J. Aesthetic Economic Code, 1rd ed.; Business Week: Taipei, Taiwan, 2009.

2. Soini, K.; Birkeland, I. Exploring the scientific discourse on cultural sustainability. Geoforum 2014, 51, $213-223$. [CrossRef]

3. Lin, J.; Cai, J.; Han, Y.; Zhu, H.; Cheng, Z. Culture sustainability: Culture quotient (CQ) and its quantitative empirical application to Chinese cities. Sustainability 2016, 8, 1235. [CrossRef]

4. Zhang, X.B. Suggestions on the market positioning and marketing strategy of the palace museum. Forbid. City J. 2016, 1, 168-181.

5. Mu, X.D. Research on the development strategy of museum cultural creation in the context of "Internet +"-Taking the Beijing Palace Museum as an example. News Res. Guide 2017, 8, 251-252.

6. Niu, L.Q. Museum “cultural and creative blue ocean". New Econ. Guide 2015, 3, 25-29.

7. Zhu, Y. 600-year-old Forbidden City is also "selling Moe" cultural and creative industry chain has not yet opened. Bus. Sch. 2017, Z1, 27-30.

8. International Council of Museums. Available online: https://icom.museum/en/activities/standardsguidelines/museum-definition/ (accessed on 15 May 2019).

9. Yang, Z. Shan Jixiang Zhou Gongxin dialogue: How cultural and creative to catch the express train museum. Ningbo Commun. 2017, 8, 70-71.

10. The Palace Museum Official Website. Available online: https://www.dpm.org.cn/About.html (accessed on 13 May 2019).

11. Chen, C. Research on the development of cultural and creative industries in the Palace Museum. Guangxi Soc. Sci. 2017, 7, 192-194.

12. China Capital Network. Available online: http://culture.qianlong.com/2016/0420/550524.shtml (accessed on 20 April 2016).

13. People's Network. Available online: http://media.people.com.cn/BIG5/n1/2019/0220/c40606-30806339.html. (accessed on 20 February 2019).

14. Shanxi Cultural Industry Network. Available online: http://www.shaanxici.cn/content/2015-09/29/content_ 13188430.htm (accessed on 29 September 2015).

15. Lin, R.T. Cultural creativity added design value. Art Apprec. 2005, 7, 1-9.

16. Hsu, C.L. Creative Cultural Products by the National Palace Museum. Master's Thesis, Department of Visual Communication Design, National Kaohsiung Normal University, Kaohsiung City, Taiwan, 2007. 
17. Chen, Y.H. The Merchandise Design of the Museum-A Case Study of Be-to Hotspring Museum. Master's Thesis, Master of Arts in the Department of Art and Design, Da-Yeh University, Changhua, Taiwan, 2008.

18. Huang, Y.C. The Cultural Product Confer Research and Concept Design: From National Museum Old is New to Formosa Plastics Group Museum Souvenir Design. Master's Thesis, Industrial Design Institute, Chang Gung University, Taoyuan City, Taiwan, 2007.

19. China Times Art Edition. Available online: http://ccindustry.pixnet.net/blog/post/16827591 (accessed on 22 April 2008).

20. Lee, C.Y. The Recollection and Learning Experience of Young Visitors by the Interaction with the Museum Souvenirs. Master's Thesis, Museum Institute Master's Program, Taipei National University of the Arts, Taipei City, Taiwan, 2009.

21. Ho, M.C.; Lin, Q.X.; Liu, Y.J. Cultural and creative concept development and design of the product. J. Des. 1996, 1, 1-15.

22. Chen, H.J.; Zhang, T. The symbolic transformation of the cultural and creative product design of Taiwan Museum. Art Lit. Masses 2012, 94-95.

23. Zhang, A.H. Research on the creative development model of museum art derivatives. Hundred Sch. Arts 2015, 31, 210-214.

24. Chen, J.Z.; Li, Y.J. Applying KANO quality model to explore the charm factor of cultural product design. J. Des. 2008, 13, 25-41.

25. Tsai, M.S. Convertibility and Application of Culture Symbols in the Process of Cultural Commodities Design-With Cases Studies of the Cultural Commodities Designed by Students of NYUST. Master's Thesis, Industrial Design Institute, National Yunlin University of Science and Technology, Yunlin, Taiwan, 2007.

26. Becker, S.G.; Jichu, Z. Interpretation of Preference-To Explore Human Behavior by Economic Methods, 1st ed.; Yuan-Liou Publishing: Taipei, Taiwan, 1999.

27. Sagoff, M. On the relation between preference and choice. J. Socio-Econ. 2003, 6, 587-589. [CrossRef]

28. China Economic Net. Available online: http://www.ce.cn/culture/gd/201801/19/t20180119_27812840.shtml (accessed on 18 January 2018).

29. Sun, Y.Y.; Wang, F. Research on the design characteristics of museum's cultural and creative products from the perspective of college students' needs-Taking the Palace Museum in Beijing as an example. Cult. Ind. Res. 2018, 2, 214-228.

30. Wang, H.Y.; Li, J. Research on intangible cultural heritage protection strategy based on consumer preference. Intang. Cult. Herit. Prot. 2010, 85-89.

31. Tu, J.C.; Cui, Y.; Liu, L.X. A Study on the preference of healing products for single office workers of various lifestyles. Sustainability 2019, 11, 2314. [CrossRef]

32. Connelly, S. Mapping sustainable development as a contested concept. Local Environ. 2007, 12, $259-278$. [CrossRef]

33. Black, A. Pillars, bottom lines, capitals and sustainability: A critical review of the discourses. Int. J. Environ. Cult. Econ. Social Sustain. 2007, 2, 107-117. [CrossRef]

34. Murphy, K. The social pillar of sustainable development: A literature review and framework for policy analysis. Sustain. Sci. Pract. Policy 2012, 8, 15-29. [CrossRef]

35. UNESCO. Cultural Column. Available online: http://www.unesco.org/new/zh/culture/ (accessed on 13 February 2017).

36. He, S.Z. Bring home the culture of the Forbidden City. China Gold News 2019, 8, 1-2.

37. Liu, S.J. An Analysis of the network marketing strategy of museum cultural and creative products-Taking the "Forbidden City Taobao" as an example. Audiovisual 2019, 1, 219-220.

38. Huang, Y. Taobao marketing analysis of museum cultural products-Take "Forbidden City Taobao" as an example. Mus. Res. 2011, 4, 83-87.

39. Shang, Y. Research and Development of Museum Art Derivatives-Take the Beijing Palace Museum as an example. Master's Thesis, China Central Academy of Fine Arts, Hangzhou, China, 2018.

40. Xing, Z.Y. Museum cultural and creative industry model and product research. Hundred Sch. Arts 2014, z1, $18-22$.

41. Wang, M.F. The Research of Symbolism in Local Culture Commodity Developing Mode-A Case Study in Nantou County. Master's Thesis, Department of Industrial Design, Tunghai University, Taichung City, Taiwan, 2007. 
42. Kuo, P.Y. A Study of Marketing Mechanism of Locally Cultural Industry-The Consumer Psychology Analyses. Master's Thesis, Architectural and Urban Design Institute, Chaoyang University of Technology, Taichung City, Taiwan, 2003.

43. Qiang, B.; Ye, C.; Yao, Z.Y. Innovative design and development thinking of museum cultural and creative products. Guangxi J. Light Ind. 2018, 34, 111-112, 114.

44. Wang, Y. An analysis of the success of the Palace Museum's cultural and creative products. Times Financ. 2018, 33, 104-105.

45. Yu, X.X.; Yang, W.J. Analysis of the design of museum cultural and creative products. Packag. World 2017, 4, 27-28.

46. Lu, J.Z.; Ma, P. Research on the development of museum cultural products from the perspective of design-Based on the analysis of the cultural products of the National Palace Museum in Taipei. Art Lit. Masses 2017, 19, 122-123.

47. Xiong, Z.Y. Analysis and Research on the Design of Museum Cultural Derivative Products. Master's Thesis, China Academy of Art, Hangzhou, China, 2010.

48. Shih, P.Y. Exploring the Innovation of Product Design from International Design Award-Winning Products. Master's Thesis, Design institute, National Taiwan University of Science and Technology, Taipei, Taiwan, 2006.

49. Xiao, X.; Wang, Y.N. Historical memory is draped in the new clothes of the times-Discussion cultural and creative programs "On the new, the Forbidden City". Publ. Wide Angle 2019, 73-75.

50. Ge, J.Q.; Yu, W.; Wang, T. Forbidden City cultural and creative product design analysis and reference study. Design 2018, 5, 103-105.

51. Zhao, Y.T. Analysis of the museum cultural and creative integrated marketing strategy in the new economy-A case study of the National Palace Museum. Technol. Econ. Guide 2018, 26, 182-183.

52. Chen, Z.K. "I got to go with the culture" - The definition and classification of cultural and creative products “3C resonance principle". Mod. Soc. 2017, 2, 103-105.

53. Zhang, F.Y. The development of museum cultural products in the context of "Internet +". Herit. Conserv. Stud. 2016, 1, 22-26.

54. Jin, Q.M.; Zhang, X. Museum of cultural and creative product development and research. J. Xi'an Univ. Archit. Technol. 2016, 42-46.

55. Zhang, G.D. Cultural and creative products should be more some less innovation "routine". China Bus. Times 2019, 3, 1 .

56. Li, B.W. Discussion on the design of cultural creative products based on brand communication. Sci. Technol. Econ. Guide 2019, 27, 167.

57. China Economic Net. Available online: https://baijiahao.baidu.com/s?id=1619607791536502366\&wfr= spider\&for $=p c$ (accessed on 12 December 2018).

58. Shehata, A.M.A.E.R.; Mostafa, M.M.I. Open museums as a tool for culture sustainability. Procedia Environ. Sci. 2017, 37, 363-373. [CrossRef]

59. Chaney, D.; Pulh, M.; Mencarelli, R. When the arts inspire businesses: Museums as a heritage redefinition tool of brands. J. Bus. Res. 2018, 85, 452-458. [CrossRef]

60. Albuquerque, M.H.F.; Delgado, M.J.B.L. Sustainable museographies: The museum shops. Procedia Manuf. 2015, 3, 6414-6420. [CrossRef]

61. Soini, K.; Dessein, J. Culture-Sustainability Relation: Towards a Conceptual Framework. Sustainability 2016, 8, 167. [CrossRef]

62. Ceschin, F.; Gaziulusoy, I. Evolution of design for sustainability: From product design to design for system innovations and transitions. Des. Stud. 2016, 47, 118-163. [CrossRef]

63. Axelsson, R.; Angelstam, P.; Degerman, E.; Teitelbaum, S.; Andersson, K.; Elbakidze, M.; Drotz, M.K. Social and cultural sustainability: Criteria, indicators, verifier variables for measurement and maps for visualization to support planning. Ambio 2013, 42, 215-228. [CrossRef] [PubMed]

(C) 2019 by the authors. Licensee MDPI, Basel, Switzerland. This article is an open access article distributed under the terms and conditions of the Creative Commons Attribution (CC BY) license (http://creativecommons.org/licenses/by/4.0/). 